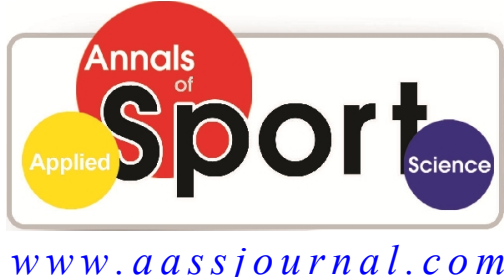

ISSN (Online): $2322-4479$

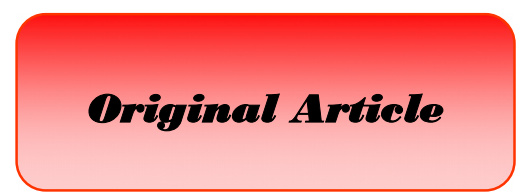

Received: $31 / 12 / 2013$

Accepted: 04/04/2014

\title{
Designing a Development Strategy for the Public Sport - a Case Study in Mazandaran Province
}

\author{
Ali Mohammad Safania* \\ - Department of Physical Education and Sport Science, Ayatollah Amoli Branch, Islamic Azad \\ University, Amol, Iran.
}

\begin{abstract}
The aim of this study was to design a development Strategy for the Public Sport in Mazandaran province. A sample of 73 individuals who were the physical education teachers of higher education institutions, senior managers of the department of the youth and sports, senior experts, heads of the state offices, provincial and municipal authorities and bodies of sports participated in this study. A researcher-made questionnaire was used to collect the data; its validity was confirmed by several experts and its reliability was confirmed through Cronbach's alpha $(\alpha=0.92)$. The questionnaire consists of 46 items rated on strengths, weaknesses, opportunities and threats to Public Sport of the province. The findings revealed that one of the main reasons for the unfavorable sports situation in Mazandaran was the lack of development strategy for Public Sport. The results of the analysis were extracted after analyzing the strengths, weaknesses, opportunities and threats and after evaluating the matrix of the internal and external factors for the Public Sport .SO strategies include the development of the sport in the state offices and the provision of sport facilities in the province. ST strategies include the provision of raw sport materials which are easily accessible to the athlete and which are with an affordable price. WO strategies include an increase of the resources and funds for improving the programs of the Public Sport. WT strategies include the use of modern sport facilities and the involvement of senior officials in the Promotion of the Public Sport.
\end{abstract}

Key Words: Public Sport, Development Strategy, SWOT. 


\section{INTRODUCTION}

Today's life style deprives us from activity and movement bringing about lots of physical, physiological, psychological, and social problems. Sports as strategic tool and public sport as a logical solution can solve such problems well (1).

Physical inactivity, along with other lifestyle-related health risk factors (e.g. consumption and use of unhealthy diet, alcohol, and tobacco), is becoming increasingly usual in developing countries which encounter rapid with economic and social development, urbanization and industrialization (2).

In general, exercise is of great importance throughout the life, it provides a good opportunity for the individuals to spend their leisure time, and it is important in maintaining the individuals' physical and mental health. So the exercise can have positive effect on the social environment, economic status, family and hereditary issues (3). According to European Charter for Regional or Minority Languages (1992), the exercise means as any form of physical activity that helps to improvement of the mental and physical health through the casual or organized participation. Sports can form the social relationships of the individuals (4). During the childhood, the sport means as a game to you, but when you get older it takes a form of competition for you. The meaning of competition has lead to the development of competitive and professional sports.

Adelkhani, Vaez Mosavi, and Farahani (2012) in study of cultural capital among participants in Sport for All (policy problems and practical solutions) based on SWOT observed that the most important proposed policies and guidelines include developing ICTs and using new technology in training and promoting culture of sport for all, establishing a sport house in scientific centers, programming deliberately and creating national infrastructure regarding sport for all, and promoting a culture based on public partnership in dealing with urban problems and social abnormally through promoting Sport for All (5).

Moeinodini and Sanatkhah (2012) in studying social and cultural factors affecting citizens' inclinations towards Public Sports (case study: the city of Kerman) showed that the variables personal conception of the body, mass media usage, and sports-centered cultural capital had direct influence on residents' inclinations towards public sports and that their effects were $0.13,0.20$, and 0.16 , respectively. The variables sportscentered social capital and sports-centered economic capital had indirect effects through sports-centered cultural capital (4).

Recent studies have shown that the media is a very important factor in the development of sport (6).

Ramezaninezhad, Rahmaninia, and Taghavi Takyar (2009) in a study of socioeconomic status and motives of participants in Sport for All indicated that the motives of "health care and fitness" and "pleasure and enjoyment" occupied the first place. "Improvement in occupational and life relationships", "prevention and treatment of diseases" and "social interaction" occupied the next place. Women gained more scores than men in all motives and married participants had higher personal reasons to participate in these activities (3).

Khaki, Tondnevis, and Mozafari (2005) investigated the development of the sport programs in Iran. The results showed that improvement of the economic status, the media, the status of the family, the competitions and awards, development of public transportation, prioritizing other areas of sport, participation of the private sectors in the sport programs are the most important factors in developing the sport programs. 
They believed that the cultural barriers can prevent from the development of sport programs, so appropriate solutions should be provided to the cultural barriers; and also, the statistics provided by the Iranian department of physical education showed that enough sport facilities are not provided for the people (7).

Today, organizations are compelled to constantly monitor the internal and external events and to adapt themselves to the changes occurring in the society. Organizations need a systematic way to identify the changes and to adapt themselves to it. The present world is changing at a staggering pace. The intuitive and experimental decisions and judgments are no longer used. Today's successful organizations will be able to use science and strategic management (8). Fry and Stoner (1995) and David (1998) define the strategic planning as a management tool designed to help the small organizations to adapt to the predicted changes $(9,10)$.

So the success of many organizations and projects can be managed by the analysis of the organization's current status (strengths and weaknesses) and by the review of external factors affecting the organization's status (opportunities and threats) (11). These observations indicate that in every organization, there is an area of responsibility that is not relevant to any specialist management: it is the strategic management. To determine its directions and objectives, a space should be created with a shared commitment for the success of the program.

Javadi Pour and Samie Nia (2013) in explanation of strategic position and presentation of development strategy in Sport for All in Iran showed that this exercise on the coordinates of SWOT in terms of internal factors in the region's strengths and the external factors of the area of opportunity lies. Based on this strategy of "aggressive and development "has been recommended for the development of mass sports. Moreover, appropriate context is provided of strengthening the culture of sport in the country, Increase active participation and cooperation of organizations, Realization Purposes of sport and national capacities in order to use all of the sport's development (11).

Seyed Ameri and Mohammad Alegh (2013) in determining techniques to attract and increase citizen, s participation in Sport for All and recreational sport programs (evidence from Urmia) showed that the offered solutions about mass media, sport facilities and complexes, sport managers and programmers and education play a significant role in attracting and increasing the participation of Urmia citizens in sport for all and recreational sport programs. Therefore, allocating more time for sport in media, planning parks and recreation courts to reinforce unstructured activities such as walking and cycling; motivating citizen to attend sport activities free of charge; and the use of the expert coaches are proposed as some techniques that can improve public participation in sport for all and recreational programs (12).

Ghofrani et al. (2009) into design and codify a developmental strategy for Public Sport in Sistan and Baluchestan province of Iran observed that out of 2.5 million populations in Sistan and Baluchestan, below $0.007 \%$ participated in public sport. If the specific geographical location of the province, unemployment rate, smuggling of fuel and narcotics as well as an outbreak of different sorts of diseases due to inactivity are taken into consideration, we can submit practical solutions (through the codification of a developmental strategy for public sport and based on the data analysis) to directors of Physical Education Organization of the province so that they can program and organize a suitable ground to improve the culture of public sports and amateur sports in the province, increase the participation and 
active cooperation of other organizations and departments, realize the goals of public sport and employ national and native capacities along with the growth and development of public sports and native sports of the province (8).

Mozafari and Gharah (2006) compared Iran's sport programs with the foreign countries; it was found that a low percent of the Iranian people participated in the sport programs compared to the people of 23 other countries. Furthermore, in 1996, 40 percent of the people participated in sport programs and in 1995 it increase to 54 percent (13).

As far as the province of Mazandaran is concerned, there is not an optimal strategy for developing the sport activities in this province. This Province has 1/46 percent of Iran's total land area $(187,502$ square kilometers) with an unemployment rate of $10 / 3 \%$.However, because of the geographical and strategic importance of this Province, investigating the important issues of this province is of importance. In 2011, around 3 million individuals lived in this province and 27362 individuals died. According to the relevant organizations, more than 10 percent of these individual died because of the lack of physical and mental health. This made the authors to conduct a study about designing a development strategy for the Public Sport to maybe can prevent such deaths.

\section{MATERIALS AND METHODS}

Descriptive analytical method was used in this study and it is an applied research because its results can be generalized to other Provinces.

Subjects. Population of the study incorporated physical education teachers of higher education institutions and senior managers of the department of the youth and sports, heads of state offices and provincial and municipal authorities and bodies of the sports; as a whole, 75 persons participated in the study. Since the population of the study was limited to 75 individuals, those who had a desire to complete the questionnaire were considered as the sample of the study. To collect the data, the relevant questionnaire was distributed among them and then the completed questioner was returned back.

Instruments. At the first stage of the study, the internet and library resources were used to collect the data and issues related to the study and the sports in Mazandaran. Furthermore, along with the internet sources and library sources, a questionnaire was developed to collect the data; this questionnaire, developed by the SWOT executive committee, sought to identify four important factors, weaknesses, strengths, opportunities and threats (SWOT), existed as for the Public Sport in the Province of Mazandaran. So, there was four parts in the questionnaire. The first part of the questionnaire with 9 questions was related to the strengths, the second part with 11 questions was related to the weaknesses, the third part with 17 questions was related to the opportunities and the fourth part with 9 questions was related to the threats. For each of these questions four answers were provided by the question developers: very good, good, average, unacceptable. It should be said that these questions were developed by considering the current status of the Public Sport in the province of Mazandaran. Furthermore, the validity of this questionnaire was checked by the experts and its reliability was 0.92 .

Statistical analysis. To describe the sport facilities and the Championships of this province, descriptive statistics was used. In this study, the means comparison test was used to check the status of the items of the questionnaire developed for measuring the strengths and weaknesses. Also to prioritize the strengths, weaknesses, opportunities and threats, friedman analysis of variance was used. 


\section{RESULTS}

Population of the study incorporated 75 individuals who were physical education teachers of higher education institutions and senior managers of the department of the youth and sports, heads of state offices and provincial and municipal authorities and bodies of the sports in the province of Mazandaran. 33.45 percent of the subjects had a bachelor degree. Most of the subjects had a degree related to the fields of physical education and sports science and 28.5 percent of the subjects aging less than $31 / 35$ years.

There is significant ranking $\left(\mathrm{x}^{2}=87.8, \mathrm{p}\right.$ $=0.001$ ) among the participants in terms of the strengths of the Public Sport in Mazandaran province (table 1). Also, table 2 Prioritize the strengths based on the rank mean.

Table 1. The rate of the strengths of the Public Sport in Mazandaran province

\begin{tabular}{|c|c|c|c|c|}
\hline Item & Mean Rank & rank & $x^{2}$ & p \\
\hline $\mathrm{S} 1$ & 6.88 & $1^{\text {st }}$ & \multirow{9}{*}{87.8} & \multirow{9}{*}{$0.001^{*}$} \\
\hline $\mathrm{S} 2$ & 4.57 & $5^{\text {th }}$ & & \\
\hline S3 & 4.30 & $8^{\text {th }}$ & & \\
\hline $\mathrm{S} 4$ & 5.28 & $3^{\text {rd }}$ & & \\
\hline S5 & 3.97 & $9^{\text {th }}$ & & \\
\hline S6 & 4.71 & $4^{\text {th }}$ & & \\
\hline $\mathrm{S} 7$ & 6.23 & $2^{\text {nd }}$ & & \\
\hline $\mathrm{S} 8$ & 4.57 & $8^{\text {th }}$ & & \\
\hline S9 & 4.50 & $7^{\text {th }}$ & & \\
\hline
\end{tabular}

Table 2. Priorities of the strengths of the Public Sport in Mazandaran province

\begin{tabular}{ccl}
\hline Priority & Item & \multicolumn{1}{c}{ Strengths (S) } \\
\hline 1 & S1 & Support of Physical Education Management from the Public Sport \\
\hline 2 & S7 & Having an interest to the athletes \\
\hline 3 & S4 & Having experts in the Department of Physical Education for the Public Sport \\
\hline 4 & S6 & Having laws for protection and enhancement of the sport \\
\hline 5 & S8 & Providing free Public Sport \\
\hline 6 & S2 & Having access to sport places and sport facilities \\
\hline 7 & S9 & Holding competitions related to the Public Sport \\
\hline 8 & S3 & Participation of young people in the sport events \\
\hline 9 & S5 & Having coaches for the Public Sport
\end{tabular}

As table 2 shows, five priorities of the strengths of the Public Sport in the province of Mazandaran are as follow: Support of Physical Education Management from the Public Sport, having an interest to the athletes, having experts in the Department of Physical Education for the Public Sport, having the laws for protection and enhancement of the sport and Providing free Public Sport.

There is significant ranking among the participants $\left(\mathrm{x}^{2}=114.4, \mathrm{p}=0.001\right)$ in terms of the weaknesses for the Public Sport in Mazandaran province (table 3). Also, table 4 shows the priorities of the weaknesses of the Public Sport in the province based on the rank mean. 
Table 3.The rate of the weaknesses of the Public Sport in the province

\begin{tabular}{|c|c|c|c|c|}
\hline Item & Mean Rank & rank & $x^{2}$ & p \\
\hline W1 & 6.52 & $4^{\text {th }}$ & \multirow{11}{*}{114.4} & \multirow{11}{*}{$0.001^{* *}$} \\
\hline W2 & 8.46 & $1^{\mathrm{st}}$ & & \\
\hline W3 & 6.75 & $2^{\text {nd }}$ & & \\
\hline W4 & 6.06 & $6^{\text {th }}$ & & \\
\hline W5 & 4.93 & $9^{\text {th }}$ & & \\
\hline W6 & 4.54 & $11^{\text {th }}$ & & \\
\hline W7 & 4.57 & $10^{\text {th }}$ & & \\
\hline W8 & 6.01 & $7^{\text {th }}$ & & \\
\hline W9 & 5.16 & $8^{\text {th }}$ & & \\
\hline W10 & 6.33 & $5^{\text {th }}$ & & \\
\hline W11 & 6.67 & $3^{\text {rd }}$ & & \\
\hline
\end{tabular}

Table 4 .Priorities of the weaknesses of the Public Sport in the province

\begin{tabular}{ccl}
\hline Priority & Item & \multicolumn{1}{c}{ Weaknesses (W) } \\
\hline 1 & W2 & Lack of long-term sport programs \\
\hline 2 & W3 & Paying little attention to the sport by the sport managers \\
\hline 3 & W11 & Having no schedule for the development of sport \\
\hline 4 & W1 & Lack of short-term sport programs \\
\hline 5 & W10 & Absence of instructions and regulations for holding the sport events \\
\hline 6 & W4 & Lack of a comprehensive and integrated information systems \\
\hline 7 & W8 & Lack of actions in the sports bodies \\
\hline 8 & W9 & Lack of quantity in sport places \\
\hline 9 & W5 & Lack of sport facilities and infrastructure \\
\hline 10 & W7 & Lack of sport facilities \\
\hline 11 & W6 & Lack of quality in the sport facilities and bases \\
\hline
\end{tabular}

As table 4 shows, five priorities of the weaknesses of the Public Sport in the province of Mazandaran are as follow: Paying little attention to the sport by the sport managers, Having no schedule for the development of sport, Lack of short-term sport programs, Absence of instructions and regulations for holding the sport events and Lacking of a comprehensive and integrated information systems.

There is significant ranking among the participants $(\mathrm{x} 2=224.7, \mathrm{p}=0.001)$ in terms of the opportunities for the Public Sport of Mazandaran province (table 5). Also, Table 6 shows the priorities of the opportunities of the Public Sport in the province based on the rank mean.
As table 6 shows, five priorities of the weaknesses of the Public Sport in the province of Mazandaran are as follow: emphasizing on the religious teachings of the exercise, popularity of the Public Sport among people, having natural places in the province, ethnic unity and Culture of the Public Sport in among the People of the Province.

There is not a significant ranking among the participants $\left(\mathrm{x}^{2}=11.13, \mathrm{p}=0.194\right)$ in terms of the treats to the Public Sport in Mazandaran province (table 7). Also, table 8 shows the dimensions of the treats of the Public Sport in the province. As it is shown in Table 8 , there is no priority and all the threats to the Public Sport are in the same level. 
Table 5.The rate of the opportunities of the Public Sport in the province

\begin{tabular}{|c|c|c|c|c|}
\hline Item & Mean Rank & rank & $x^{2}$ & p \\
\hline $\mathrm{O} 1$ & 13.38 & $1^{\mathrm{st}}$ & \multirow{17}{*}{224.7} & \multirow{17}{*}{$0.001^{* *}$} \\
\hline $\mathrm{O} 2$ & 11.82 & $2^{\text {nd }}$ & & \\
\hline O3 & 9.27 & $8^{\text {th }}$ & & \\
\hline $\mathrm{O} 4$ & 11.68 & $3^{\text {rd }}$ & & \\
\hline O5 & 9.22 & $9^{\text {th }}$ & & \\
\hline O6 & 10.72 & $4^{\text {th }}$ & & \\
\hline $\mathrm{O} 7$ & 9.09 & $10^{\text {th }}$ & & \\
\hline O8 & 9.69 & $6^{\text {th }}$ & & \\
\hline O9 & 6.75 & $15^{\text {th }}$ & & \\
\hline O10 & 7.10 & $13^{\text {th }}$ & & \\
\hline O11 & 7.15 & $20^{\text {th }}$ & & \\
\hline $\mathrm{O} 12$ & 9.68 & $5^{\text {th }}$ & & \\
\hline O13 & 6.96 & $14^{\text {th }}$ & & \\
\hline O14 & 8.90 & $11^{\text {th }}$ & & \\
\hline O15 & 6.63 & $16^{\text {th }}$ & & \\
\hline O16 & 9.37 & $7^{\text {th }}$ & & \\
\hline $\mathrm{O} 17$ & 5.40 & $17^{\text {th }}$ & & \\
\hline
\end{tabular}

Table 6 .Priorities of the opportunities of the Public Sport in the province

\begin{tabular}{ccl}
\hline Priority & Item & \multicolumn{1}{c}{ Opportunities (O) } \\
\hline 1 & O1 & Emphasizing on the religious teachings of the exercise \\
\hline 2 & O2 & Popularity of the Public Sport among the people \\
\hline 3 & O4 & Having natural places in the province \\
\hline 4 & O6 & Ethnic unity \\
\hline 5 & O12 & Culture of the Public Sport among the People of the Province \\
\hline 6 & O8 & Atmospheric conditions (no need of indoor facilities) \\
\hline 7 & O16 & Encouraging by the broadcasting \\
\hline 8 & O3 & Multiplicity of sports media \\
\hline 9 & O5 & Support and supervision of officials \\
\hline 10 & O7 & Activities of the sports bodies \\
\hline 11 & O14 & Participation in the Public Sport \\
\hline 12 & O11 & Interaction and coordination between the offices of the Province \\
\hline 13 & O10 & Attention of the authorities of the province to the Public Sport \\
\hline 14 & O13 & Radio and television programs \\
\hline 15 & O9 & Exercises among the employees \\
\hline 16 & O15 & Participation of the private sector in the Public Sport \\
\hline 17 & O17 & Understanding the role of Public Sport \\
\hline
\end{tabular}

Table 7.The rate of the threats of the Public Sport in the province

\begin{tabular}{ccccc}
\hline Item & Mean Rank & rank & $\mathbf{x}^{2}$ & $\mathbf{p}$ \\
\hline $\mathrm{T} 1$ & 4.60 & - & & \\
\hline $\mathrm{T} 2$ & 5.40 & - & & \\
\hline $\mathrm{T} 3$ & 4.84 & - & & \\
\hline $\mathrm{T} 4$ & 4.84 & - & & \\
\hline $\mathrm{T} 5$ & 4.71 & - & & \\
\hline $\mathrm{T} 6$ & 5.44 & - & & \\
\hline $\mathrm{T} 7$ & 5.31 & - & & \\
\hline $\mathrm{T} 8$ & 5.19 & - & & \\
\hline $\mathrm{T} 9$ & 4.66 & - & & \\
\hline
\end{tabular}


Table 8. Dimensions of the threats of the Public Sport in the province

\begin{tabular}{c|c|l}
\hline Priority & Item & \multicolumn{1}{c}{ Threats (T) } \\
\hline 1 & T1 & Unemployment rate in the province \\
\hline 2 & T2 & Increase of drug addicts \\
\hline 3 & T3 & Increase of the prices of the Sport equipments \\
\hline 4 & T4 & Politicization of the sport fields \\
\hline 5 & T5 & Increased costs of the halls maintenance \\
\hline 6 & T6 & Lives of machine people \\
\hline 7 & T7 & Urban restructuring \\
\hline 8 & T8 & Little attention to the sports by governor \\
\hline 9 & T9 & Not supporting the management of Physical Education \\
\hline
\end{tabular}

The score of the matrix of the internal factors is more than $5.2(9.2)$, and this suggests that from the perspective of the internal factors the sport has a strong place in the province of Mazandaran (table 9).

Table 9. The matrix of the internal factors

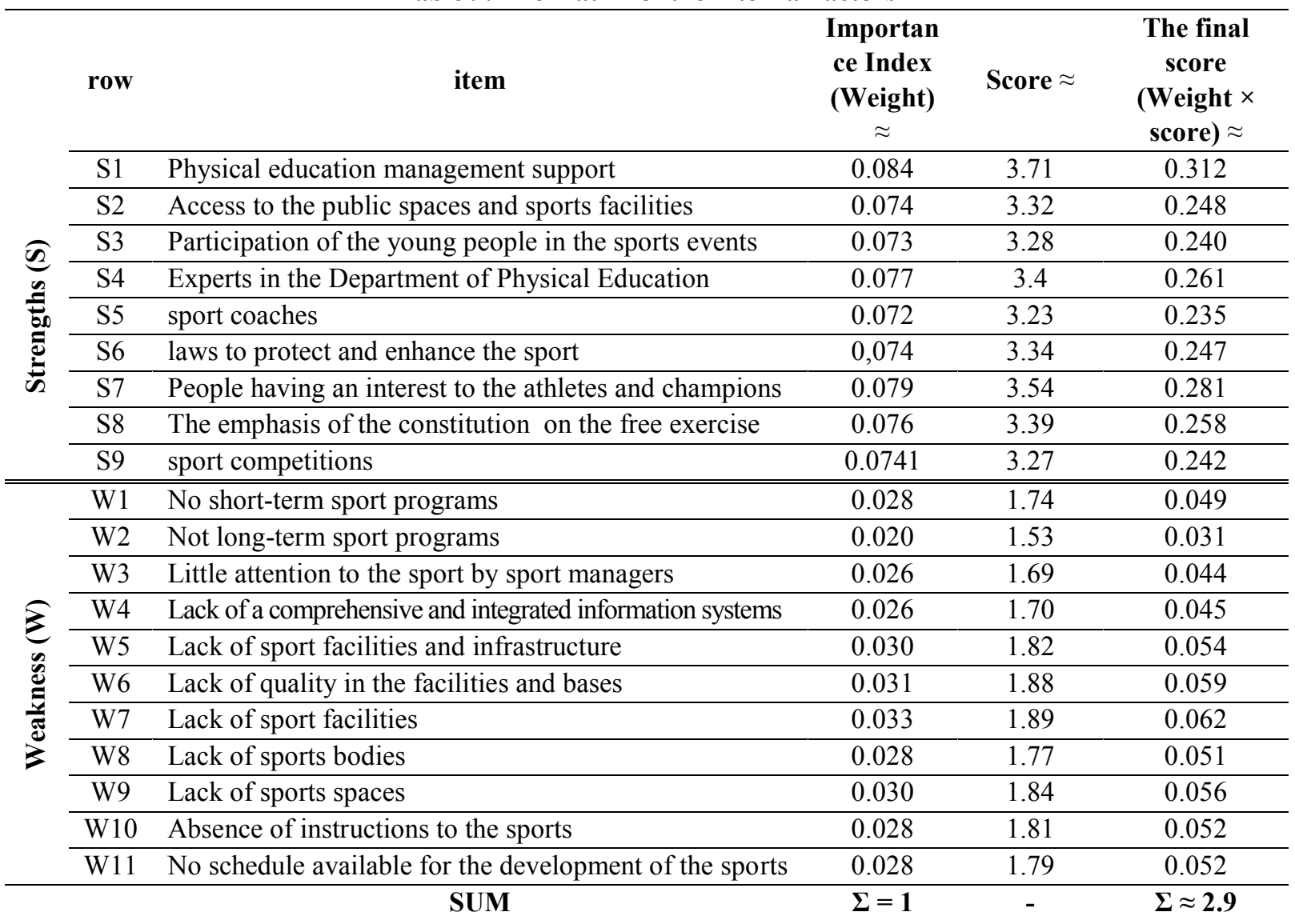

The score of the matrix of the external factors is more than 2.5 (3.2), and this suggests that from the perspective of the external factors, the province of Mazandaran has good sport opportunities (table 10). 
Table 10. The matrix of the external factors

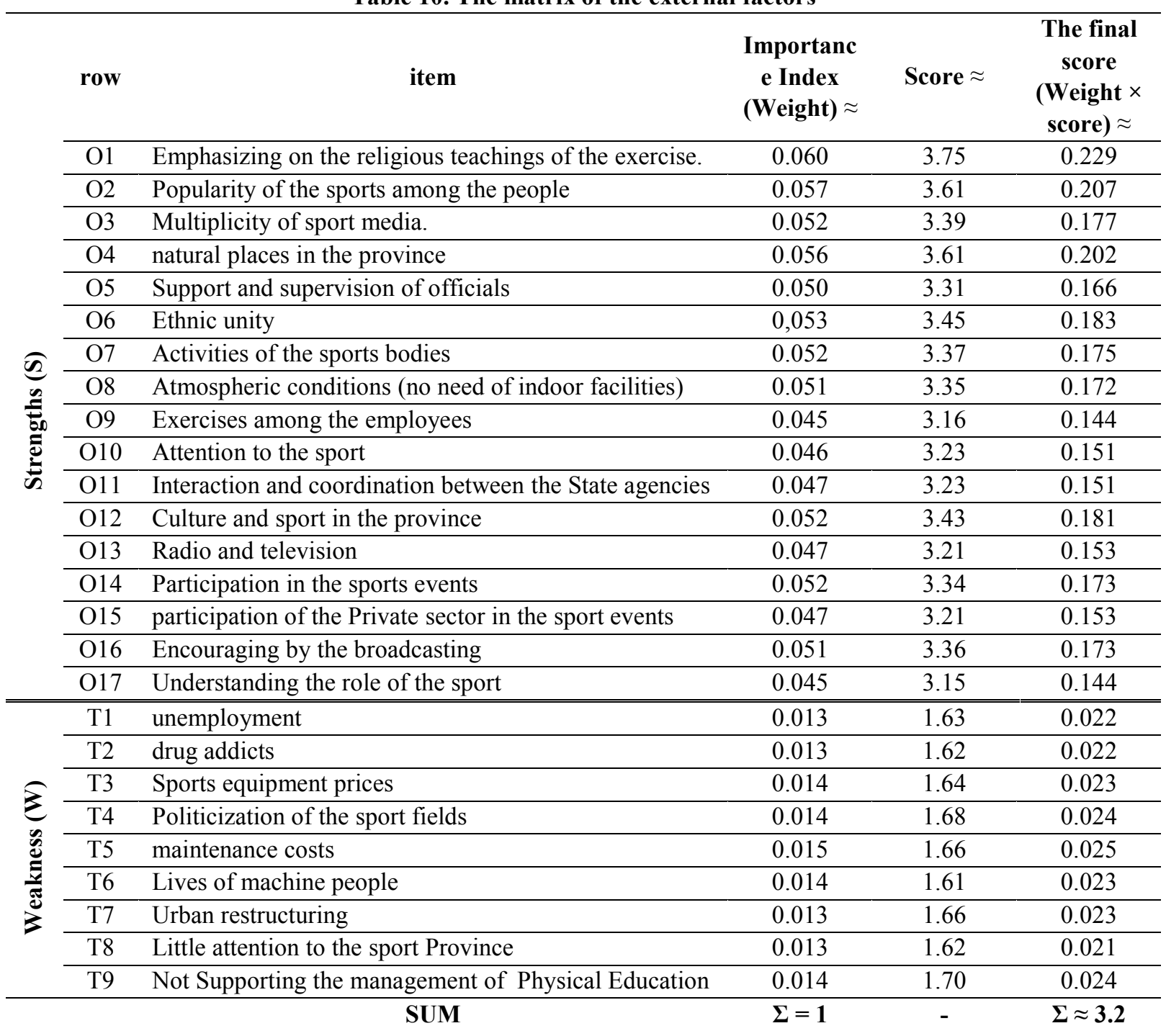

To determine the "Strategic Position and Action Evaluation Matrix (SPACEM)" of the department of Physical Education through the matrix, the scores of the internal factors were put in the horizontal line and the scores of the external factors were put in the vertical line (figure 1).

\section{DISCUSSION and CONCLUSION}

Results of the tables 9 and 10 as well as the internal and external matrix imply that the sport of the province is located in the SO region of the strategic position, so the sport of the Province has strong place in terms of the internal factors and have opportunities in terms of the external factors. Based on the final scores of the matrix of the internal and external factors appropriate strategies should be developed by the physical education department of the Province. In the SWOT analysis, a total of 20 were provided. Six SO strategies, five ST strategies, seven WO strategies and two WT strategies were developed for the Public Sport of the Province. Tables 11, 12, 13 and 14 show these strategies. 


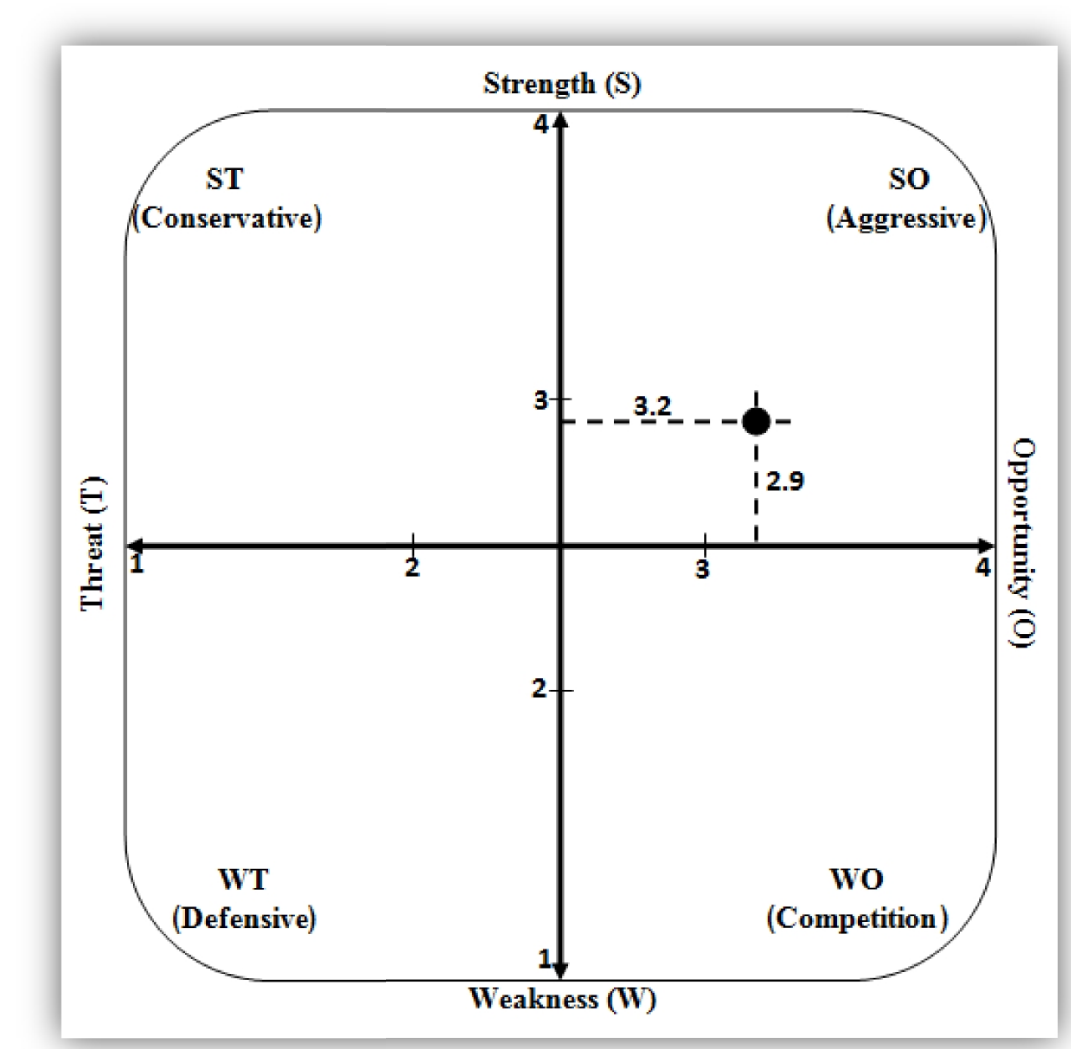

Figure 1. SWOT graph indicating Strategic Position and Action Evaluation Matrix (SPACEM) of the Public Sport in Mazandaran province.

\section{SO strategies:}

The most favorable position for the organization is to use all its positive points and its benefits to maximize the opportunities and demands. The goal of any organization is moving from SWOT position of the matrix to the SO position. If these organizations be able to identify their weaknesses and try to fix them, they will not have severe problems.

\section{ST strategies:}

The objective of these strategies is to obtain Maximum utilization of the organization's internal strengths to deal with the threats and to minimize their harmful environmental bottlenecks. Therefore, an organization must use its strengths in the areas of technology, finance, management, operations, production, engineering and marketing to encounter with threats and bottlenecks.

\section{WO strategies:}

The objective of these strategies is to reduce and to minimize the weaknesses and vulnerable aspects of the organization and to maximize the opportunities, situations and demands. Therefore, the organizations must remove the weaknesses and vulnerabilities of the organization and use the new technology and skillful workforce to solve their problems.

\section{WT strategies:}

Their aim is to reduce and to minimize the weaknesses and vulnerable aspects of the organization as well as the external threats and dilemmas. To prevent from the problems the organizations should reconstruct, assess and evaluate itself. 
Table 11. SO strategies

\begin{tabular}{|c|c|}
\hline $\begin{array}{l}\text { Strength (S) } \\
\text { 1. Protection administration of the physical education } \\
\text { 2. Access to the sport places } \\
\text { 3. Sport experts } \\
\text { 4. Sport coaches } \\
\text { 5. Terms of protecting and enhancing the sports } \\
\text { 6. Public interest to the athletes } \\
\text { 7. Providing free Public Sport } \\
\text { 8. Sport competition }\end{array}$ & External Factors \\
\hline SO strategies & Opportunities (O) \\
\hline $\begin{array}{l}\text { 1. Sports Development in the Office of } \mathrm{S}_{1}, \mathrm{O}_{5}, \mathrm{O}_{10} \text {, } \\
\mathrm{O}_{11} \\
\text { 2. Bases in sport } \mathrm{S}_{2}, \mathrm{O}_{14} \\
\text { 3. Taking advantage of the natural spaces for the } \\
\text { development of sport } \mathrm{S}_{2}, \mathrm{O}_{4}, \mathrm{O}_{12} \\
\text { 4. Developing and promoting the sport in the } \\
\text { province. } \mathrm{S}_{5}, \mathrm{~S}_{4}, \mathrm{O}_{14} \\
\text { 5. Tournament host country } \mathrm{S}_{9}, \mathrm{O}_{15}, \mathrm{O}_{14}, \mathrm{O}_{11} \\
\text { 6. Development of Public Sports venues } \mathrm{S}_{3}, \mathrm{O}_{5}\end{array}$ & $\begin{array}{l}\text { 1. Emphasis on addressing the exercise of religious teachings. } \\
\text { 2. Popularity of sport among the people } \\
\text { 3. Multi-media } \\
\text { 4. Having natural places in the province. } \\
\text { 5. Support and supervision of the authorities } \\
\text { 6. Ethnic unity of the spirit } \\
\text { 7. Activities of the sports bodies } \\
\text { 8. Atmospheric conditions (no need of indoor facilities) } \\
\text { 9. Exercises among the employees } \\
\text { 10. State authorities in respect of exercising the disabled } \\
\text { 11. Coordination to holding the competitions } \\
\text { 12. Culture of the sport in the province. } \\
\text { 13. Broadcasting the programs } \\
\text { 14. Participation of the people in the sport events } \\
\text { 15. Participation of the private sector in sport events } \\
\text { 16. By encouraging the broadcasting } \\
\text { 17. Understanding the role of sport by people }\end{array}$ \\
\hline
\end{tabular}

Table 12. ST strategies

\begin{tabular}{|c|c|}
\hline Strength (S) & \\
\hline $\begin{array}{l}\text { 1. Protection Administration of Physical Education } \\
\text { 2. Access to the sport places } \\
\text { 3. Sport Experts } \\
\text { 4. Sport coaches } \\
\text { 5. Laws of protecting and enhancing the sport } \\
\text { 6. Public interest to the athletes } \\
\text { 7. Providing free Public Sport } \\
\text { 8. Sport Competitions } \\
\text { 9. Presence of the youth and adolescents in sport }\end{array}$ & External factors \\
\hline $\begin{array}{l}\text { Strategies ST } \\
\end{array}$ & Threats (T) \\
\hline $\begin{array}{l}\text { 1. Developing programs to promote the sports among the } \\
\text { youth } \mathrm{S}_{3}, \mathrm{~T}_{1}, \mathrm{~T}_{2} \\
\text { 2. Informing people about the effects of exercise } \mathrm{S}_{4}, \mathrm{~S}_{5} \text {, } \\
\mathrm{T}_{1}, \mathrm{~T}_{2} \\
\text { 3. providing basic supplies for the athletes at affordable } \\
\text { prices } \mathrm{S}_{8}, \mathrm{~T}_{4} \\
\text { 4. Easy access to the public sport places, } \mathrm{S}_{7}, \mathrm{~S}_{8}, \mathrm{~T}_{5} \mathrm{~S} \\
\text { 5. The creation of reaction of the necessary Sport Touring } \\
\mathrm{S}_{2}, \mathrm{~S}_{8}, \mathrm{~T}_{7}\end{array}$ & $\begin{array}{l}\text { 1. High the unemployment rate } \\
\text { 2. Increase of the Addicts } \\
\text { 3. The rising cost of sports equipment } \\
\text { 4. The politicization of sports fields } \\
\text { 5. Increased maintenance costs of Halls } \\
\text { 6. The lives of machined people } \\
\text { 7. Change of the structure of cities } \\
\text { 8. Less attention to the sport by the governor } \\
\text { 9. Supporting the management of Physical Education }\end{array}$ \\
\hline
\end{tabular}




\begin{tabular}{|c|c|}
\hline \multicolumn{2}{|c|}{ Table 13. WO strategies } \\
\hline Weaknesses (W) & \multirow[b]{2}{*}{ External factors } \\
\hline $\begin{array}{l}\text { 1. Lack of the short-term sport programs } \\
\text { 2. Lack of long-term sport programs } \\
\text { 3. Lack of attention to the sport by the sport managers. } \\
\text { 4. Lack of a comprehensive and integrated } \\
\text { information systems } \\
\text { 5. Lack of infrastructure facilities for Sport } \\
\text { 6. Lack of sport facilities } \\
\text { 7. Lack of action in the sports bodies } \\
\text { 8. Lack of quality in the sport places } \\
\text { 9. No instructions to the sports } \\
\text { 10. No schedule available for the development of sport }\end{array}$ & \\
\hline Strategies WO & Opportunities (O) \\
\hline $\begin{array}{l}\text { 1. Increasing the resources and funding for the } \\
\text { sports } \mathrm{W}_{5}, \mathrm{O}_{10}, \mathrm{O}_{15}\end{array}$ & $\begin{array}{l}\text { 1. Emphasizing on the exercise in religious teachings. } \\
\text { 2. Popularity of the sports among the people }\end{array}$ \\
\hline 2. Use of financial resources of the private sector & 4. Natural places in the province. \\
\hline for helping the sports $\mathrm{W}_{5}, \mathrm{~W}_{2}, \mathrm{~W}_{7}, \mathrm{O}_{15}$ & $\begin{array}{l}\text { 5. Support and supervision authorities in the exercise of public } \\
\text { 6. Ethnic unity }\end{array}$ \\
\hline 3. Using the power of media to promote the sports $\mathrm{O}_{3}, \mathrm{~W}_{11}$ & 7. Sport Boards Activity \\
\hline & 8. Atmospheric conditions (no need of indoor facilities) \\
\hline 4. Holding different Matches $\mathrm{W}_{11}, \mathrm{O}_{14}$ & 9. Exercises among the employees \\
\hline & 10. Attention of the sport for the disabled \\
\hline 5. Taking advantage of the expertise in the & 11. Interaction and coordination between the departments \\
\hline development of sport $\mathrm{W}_{3}, \mathrm{O}_{5}, \mathrm{O}_{10}$ & $\begin{array}{l}\text { 12. Culture of sport in the province. } \\
\text { 13. Culture of Public Sport in the province }\end{array}$ \\
\hline 6. Holding Tournament in the tribal and rural level & 14. Radio and television \\
\hline $\mathrm{W}_{11}, \mathrm{O}_{6}$ & 15. Participation of the people in the sport events \\
\hline & 16. Participation of the private sector in the sport events \\
\hline 7. Development of radio and television programs & 17. By encouraging the broadcasting \\
\hline about sports $\mathrm{W}_{11}, \mathrm{O}_{16}$ & 18. Understanding the role of sport \\
\hline
\end{tabular}

\begin{tabular}{|c|c|}
\hline \multicolumn{2}{|c|}{ Table 14. WT strategies } \\
\hline Weaknesses (W) & \\
\hline $\begin{array}{l}\text { 1. Lack of the short-term sport programs } \\
\text { 2. Lack of long-term sport programs } \\
\text { 3. Lack of attention to the sport by the sport managers. } \\
\text { 4. Lack of a comprehensive and integrated information systems } \\
\text { 5. Lack of infrastructure facilities for the Sports } \\
\text { 6. Lack of sport facilities } \\
\text { 7. Lack of action in the sports bodies } \\
\text { 8. Lack of quality in the sport places } \\
\text { 9. No instructions to the sports } \\
\text { 10. No schedule available for the development of the sports }\end{array}$ & Internal Factors \\
\hline strategies WT & Threats (T) \\
\hline $\begin{array}{l}\text { Updating the sports facilities } \mathrm{W}_{5}, \mathrm{~W}_{6}, \mathrm{~W}_{7}, \text { and } \mathrm{T}_{5} \text {--- Senior } \\
\text { officials in the use of sport development. } \mathrm{T}_{8}, \mathrm{~W}_{11}\end{array}$ & $\begin{array}{l}\text { 1. High the unemployment rate } \\
\text { 2. Increase of the Addicts } \\
\text { 3. The rising cost of the sport equipments } \\
\text { 4. The politicization of sports fields } \\
\text { 5. Increased maintenance costs of Halls } \\
\text { 6. The lives of machined people } \\
\text { 7. Change of the structure of cities } \\
\text { 8. Less attention to the sport by the governor } \\
\text { 9. Not supporting the management of the } \\
\text { Physical Education }\end{array}$ \\
\hline
\end{tabular}




\section{Proclamation of the Public Sport in the Province of Mazandaran:}

Development of the Public Sport in the classes of the Province of Mazandaran.

Mission of the Public Sport in the province:

The underlying causes for the development of sport programs are improvement of the life, enrichment of the leisure time, encouragement of mobility and the improvement of life.

Long-term goals of the Public Sport in the province:

1. Participation of 7 percent of the people involved in the Public Sport programs
2. Promotion of sports space per 1 square meter

The prioritized main strategies in the province:

The main development strategies of the province of Mazandarn included making culture in the sport, financial strengthening of the athletes, sport development strategy, investment of the private sector in the sport programs, creation of the right talent with the right patterns and the promotion of the sport industries.

\section{REFFRENCES}

1. Momtaz Bakhsh M, Fakour Y. Strategies for Developing Female Public Exercises in I.R.I Police University. Danesh-E-Entezami. 2007;9(2):53-62 [Article in Farsi].

2. Bauman A, Schoeppe S, Lewicka M, Armstrong T, Candeias V, Richards J. Review of Best Practice in Interventions to Promote Physical Activity in Developing Countries. "Center for Physical Activity and Health, School of Public Health, University of Sydney, Australia" and "WHO Headquarters, Geneva, Switzerland", 2005.

3. Ramezaninezhad R, Rahmaninia F, Taghavi Takyar SA. A Study of Socioeconomic Status and Motives of Participants in Sport for All. Sport Management (Harakat). 2009(2):5-19 [Article in Farsi].

4. Moeinodini J, Sanatkhah A. Studying Social and Cultural Factors Affecting Citizens' Inclinations towards Public Sports (Case Study: The City of Kerman). Urban Studies. 2012;2(3):149-78 [Article in Farsi].

5. Adelkhani A, Vaez Mosavi SMK, Farahani A. Cultural Capital among Participants in Sport for All (Policy Problems and Practical Solutions). Majlis \& Rahbord. 2012;19(69):5-32 [Article in Farsi].

6. Aghajani N, Naderi Nejad P. Study the Role of Mass Media (Television, Magazines and Radio) On Diffusion of Sport Culture for All in Iranian Society. Culture of Communication. 2011;1(1):139-67 [Article in Farsi].

7. Khaki AA, Tondnevis F, Mozafari SAA. The Comparative Study Of The Viewpoints Of Participants, Coaches, Directors, And Faculty Members About Developing Of "Sport For All" In Iran. Journal of Movement Science \& Sports. 2005;3(5):1-22 [Article in Farsi].

8. Ghofrani M, Goudarzi M, Sajadi NA, Jalali Faraahani M, Mogharnasi M. To Design and Codify a Developmental Strategy for Public Sport in Sistan and Baluchestan. Harakat 2009(39):107-31 [Article in Farsi].

9. Fry FL, Stoner CR. Strategic Planning for the New and Small Business: Upstart Publishing Company; 1995.241 p.

10. David FR. How companies define their mission. Long Range Planning. 1989;22(1):90-7.

11. Javadi Pour M, Samie Nia M. Explanation of Strategic Position and Presentation of Development Strategy in Sport for All in Iran. Management of Sport And Movement Sciences. 2013;3(5):15-28 [Article in Farsi].

12. Seyed Ameri MH, Mohammad Alegh GB. Determining Techniques to Attract and Increase Citizen, S Participation in Sport for All and Recreational Sport Programs (Evidence from Urmia). Management of Sport And Movement Sciences. 2013;2(4):23-34 [Article in Farsi].

13. Mozafari SAA, Gharah MA. Sport For All In Iran And Comparing With Some Selected Countries. Journal of Movement Science \& Sports. 2006;3(6):151-71 [Article in Farsi]. 


\title{
تازههاى علوم كاربردى ورزش \\ دوره دوم، شماره اول

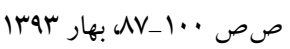 \\ تاريخ دريافت: $11 \mid$

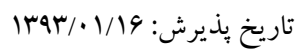 \\ طر احى راهبرد توسعه ورزش همًانى استان مازندران \\ * على محمد صفانيا
}

مقاله اصيل

\author{
كروه تربيت بدنى و علوم ورزشى، دانشخاه آزاد اسلامى واحد آيتالهه آملى، آمل، ايران.
}

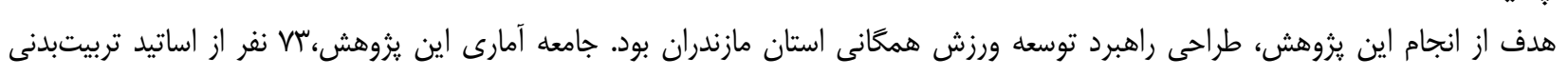

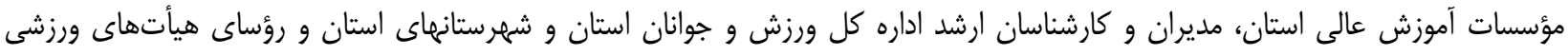

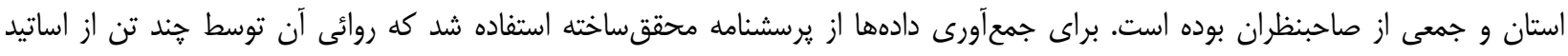

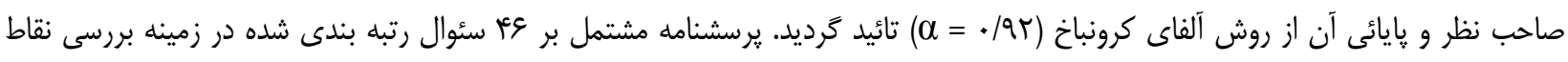

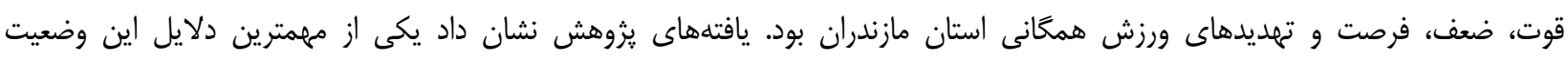

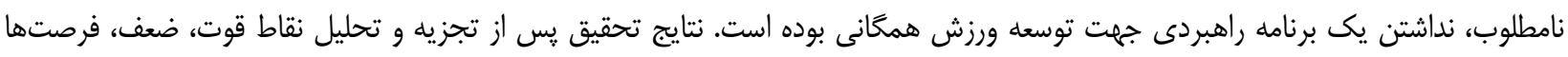

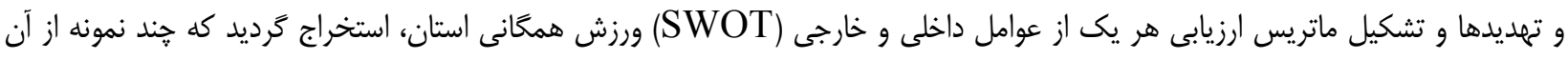

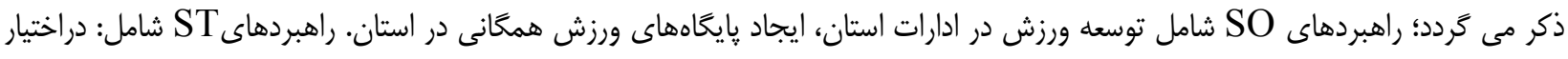

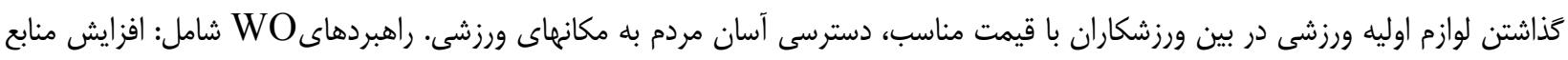

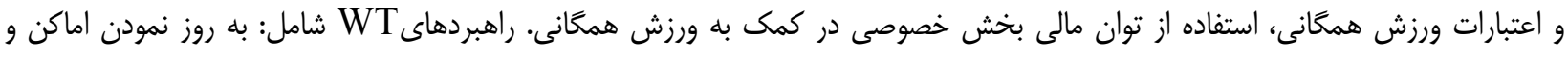

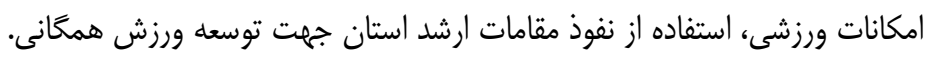

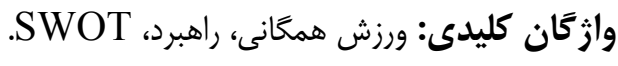

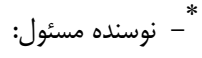

على محمد صفانيا
}

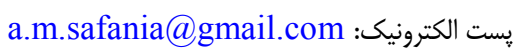

